\title{
Baseline Sensitivities of Fungal Pathogens of Fruit and Foliage of Citrus to Azoxystrobin, Pyraclostrobin, and Fenbuconazole
}

\author{
S. N. Mondal, Alka Bhatia, Turksen Shilts, and L. W. Timmer, University of Florida, Citrus Research and Educa- \\ tion Center, Department of Plant Pathology, 700 Experiment Station Road, Lake Alfred 33850 USA
}

\begin{abstract}
Mondal, S. N., Bhatia, A., Shilts, T., and Timmer, L. W. 2005. Baseline sensitivities of fungal pathogens of fruit and foliage of citrus to azoxystrobin, pyraclostrobin, and fenbuconazole. Plant Dis. 89:1186-1194.

The baseline sensitivities for mycelial growth of foliar fungal pathogens of citrus, Colletotrichum acutatum, Alternaria alternata, Elsinoe fawcettii, Diaporthe citri, and Mycosphaerella citri, the causal agents of postbloom fruit drop, brown spot of tangerine, citrus scab, melanose, and greasy spot, respectively, were determined in vitro for azoxystrobin, pyraclostrobin, and fenbuconazole. The effective dose to reduce growth by $50 \%$ ( $\mathrm{ED}_{50}$ values) was determined for each pathogen-fungicide combination using five isolates from different citrus areas of Florida and eight fungicide concentrations. A discriminatory dose for each combination was selected near the $\mathrm{ED}_{50}$, and the range of sensitivity of 50 to 62 isolates of each fungal species was determined. The effect of salicylhydroxamic acid (SHAM) on the sensitivity of the five fungal species to azoxystrobin and pyraclostrobin was determined. Since mycelial growth of A. alternata was insensitive to azoxystrobin, the effect of that fungicide with and without SHAM on spore germination was assessed. The $\mathrm{ED}_{50}$ values for most fungal pathogens of citrus were relatively high compared with foliar pathogens of other tree crops. Values for azoxystrobin ranged from a low of $0.06 \mu \mathrm{g} / \mathrm{ml}$ with E. fawcettii to a high of $>100 \mu \mathrm{g} / \mathrm{ml}$ with A. alternata. With pyraclostrobin, the values ranged from a low of $0.019 \mu \mathrm{g} / \mathrm{ml}$ with $D$. citri to a high of $0.87 \mu \mathrm{g} / \mathrm{ml}$ with A. alternata. With fenbuconazole, the lowest $\mathrm{ED}_{50}$ value was $0.21 \mu \mathrm{g} / \mathrm{ml}$ with $M$. citri and the highest was $1.01 \mu \mathrm{g} / \mathrm{ml}$ with $C$. acutatum, but $A$. alternata and D. citri were not tested. SHAM was inhibitory to all species and reduced growth of $D$. citri greatly. Inclusion of SHAM in the medium did not greatly affect the sensitivity of mycelial growth of these fungi to azoxystrobin or pyraclostrobin, nor did it affect the $\mathrm{ED}_{50}$ values for conidial germination of A. alternata. The coefficients of variation for the sensitivity of 50 to 62 isolates of each species to these fungi ranged from $7.3 \%$ with the pyraclostrobin-C. acutatum combination to a high of $55.0 \%$ with the fenbuconazole-M. citri combination. Discriminatory doses have been established for these pathogenfungicide combinations that should be useful for detecting major shifts in fungicide sensitivity.
\end{abstract}

Fungal pathogens of fruit and foliage cause serious losses to the Florida citrus industry and reduce yield and fruit quality $(37,39,40)$. Postbloom fruit drop (PFD), caused by Colletotrichum acutatum, affects flowers and results in abscission of young fruitlets and the formation of persistent calyces. Losses are greatest on Navel and Valencia sweet oranges (Citrus sinensis) in years where significant rainfall occurs during the bloom period. Alternaria brown spot, caused by Alternaria alter$n a t a$, affects tangerines and their hybrids and produces lesions on fruit, leaves, and twigs. The disease has become more widespread in recent years and affects yield and

Corresponding author: L. W. Timmer

E-mail: lwt@crec.ifas.ufl.edu

This research was supported in part by the Florida Agricultural Experiment Station and approved for publication as Journal Series R-10417.

Accepted for publication 22 June 2005.

DOI: 10.1094/PD-89-1186

(C) 2005 The American Phytopathological Society fruit quality of high-value cultivars such as Murcotts $(C$. sinensis $\times C$. reticulata $)$ and Minneola tangelos (C. paradisi $\times C$. reticulata). Citrus scab, caused by Elsinoe fawcettii, exhibits warty pustules on the leaves, twigs, and fruit of susceptible citrus species. The disease causes external blemishes and reduces the acceptability of grapefruit and many tangerines and their hybrids produced for the fresh market. Melanose, caused by Diaporthe citri, exhibits brick red lesions on the fruit, leaves, and twigs of most citrus. This disease reduces the value of fruit for the fresh market and is most important on grapefruit $(C$. paradisi), navel oranges, and tangerines (C. reticulata) and their hybrids. Greasy spot, caused by Mycosphaerella citri, exhibits lesions on mature leaves and rind blotch on fruit of most citrus. The leaf lesions induce premature leaf drop and can affect yield and fruit size of all citrus. Rind blotch is most serious on grapefruit grown for the fresh market.

Modifications of cultural practices are helpful in reducing the impact of these diseases, but the primary means of control is by application of fungicides (37). For postbloom fruit drop, one to two welltimed sprays during bloom are usually sufficient for disease control, even in years with rain during the bloom. Benzimidazole fungicides, such as benomyl or thiophanate methyl, have been the most effective for disease control, but strobilurins also control the disease $(31,32,41)$. Benomyl has been withdrawn from the market, and thiophanate methyl has only an emergency registration for use on Florida citrus (29). Alternaria brown spot is difficult to control, and sprays may be needed every 7 to 10 days from the beginning of growth in the spring to mid-July, when the fruit becomes resistant. Copper and strobilurin fungicides are the primary products used for control of brown spot. For control of citrus scab, up to three applications may be needed to protect the new growth and young fruit in the spring. Ferbam and the strobilurin fungicides are currently recommended, but fenbuconazole is also very effective $(29,34,38,49)$. Melanose is controlled by several fungicide applications from late April until early July when the fruit become resistant. Copper and strobilurin fungicides are the most effective products for melanose control (1). For greasy spot control on foliage, one or two fungicide applications are needed in early to midsummer, and an additional spray may be required for rind blotch control on fruit. A wide range of products is effective for greasy spot control, including petroleum oils, copper fungicides, fenbuconazole, and strobilurins.

The strobilurin fungicides, azoxystrobin, pyraclostrobin, and trifloxystrobin, have recently been registered for use on citrus in Florida (37). Fenbuconazole currently has an emergency registration for control of greasy spot on grapefruit. This fungicide is also quite effective for control of scab $(13,49)$ and potentially useful for postbloom fruit drop. Fenbuconazole is much less effective for control of Alternaria brown spot and melanose $(13,37,49)$. Fenbuconazole is the only sterol-biosynthesisinhibiting fungicide ever registered on citrus in Florida.

Little research has been conducted on the fungicide sensitivity of any of the fungal pathogens of fruit and foliage, and little is known about effective resistance management of fungicides for citrus. Benomyl was first registered in the early 1970s, and $M$. citri, the greasy spot pathogen, quickly developed resistance (43). E. fawcettii, the 
causal agent of citrus scab, developed resistance to benomyl as well (34), but resistance is not nearly as widespread. Benomyl was recommended for scab, but not greasy spot, control until recently when it was withdrawn from the market.

Baseline sensitivity of some important fungal pathogens of other crops to the strobilurin fungicides has been established $(25,47,48)$. Resistance of these fungi has developed on several different plants $(4,5,18-20,42)$. Baseline sensitivities of several pathogens to fenbuconazole and other triazole fungicides have been determined as well $(20,33,34)$. Although large shifts in the sensitivity of isolates has not occurred, resistance is a problem nevertheless $(20,21,34)$.

Three strobilurin fungicides are now fully registered on citrus, and fenbuconazole could be fully registered in the near future. The objective of this research was to establish the baseline sensitivity of the major citrus fungal pathogens to these products prior to their widespread use. This information should facilitate detection and verification of the development of resistance to these products.

\section{MATERIALS AND METHODS}

Isolation and storage of fungal pathogens. Since the intent was to establish baseline sensitivity values for the major fungal pathogens of citrus, all isolates were collected from groves not previously treated with the fungicides studied. All of the isolates collected early in the 1990s would never have been exposed to any of these products since these fungicides were not yet available. Subsequently, isolates were collected from abandoned groves or where the fungicide usage in the blocks had been verified with the grower. All isolates of $C$. acutatum were obtained from flower petals of sweet oranges affected by postbloom fruit drop. Symptomatic petals were dipped in $70 \%$ ethanol for $30 \mathrm{~s}$, then in $1 \%$ sodium hypochlorite for $1 \mathrm{~min}$, then rinsed with sterile distilled water and blotted dry on sterilized filter paper $(28,30)$. Tissue pieces were plated on potato dextrose agar (PDA) and incubated at 24 to $27^{\circ} \mathrm{C}$. All isolates were identified as $C$. acutatum by colony morphology, conidial shape, and their ability to grow on PDA + $10 \mu \mathrm{g} / \mathrm{ml}$ benomyl (30).

All of the isolates of A. alternata were of the tangerine pathotype $(39,40)$. Leaf tissue of affected tangerines or tangerine hybrids with typical symptoms of Alternaria brown spot was collected. Tissue pieces about $4 \mathrm{~mm}^{2}$ were dipped in $95 \%$ ethanol for $10 \mathrm{~s}$, in $1 \%$ sodium hypochlorite for $60 \mathrm{~s}$, rinsed with sterile, distilled water, blotted dry on sterile filter paper, and plated on PDA $+10 \mu \mathrm{g} / \mathrm{ml}$ benomyl (31). Since the tangerine pathotype is morphologically indistinguishable from saprophytes and other pathotypes (29), pathogenicity was verified by inoculating young leaves of Minneola tangelo in vitro (15).

Isolates of E. fawcettii were collected from affected leaves or fruit. Fruit or leaves were washed thoroughly with soap and water and allowed to dry for 2 to 3 days. Symptomatic tissues were dipped in 95\% ethanol and allowed to air dry. Using a scalpel, small flakes of affected tissues were scraped from the surface and allowed to fall on the selective medium consisting of PDA + $400 \mathrm{mg}$ of dodine, and $100 \mathrm{mg}$ each of streptomycin and tetracycline per liter (46). Cultures were incubated at 24 to $27^{\circ} \mathrm{C}$ for about 10 days, and typical colonies of E. fawcettii were selected (39) and transferred to fresh PDA.

For isolation of D. citri, twigs affected by melanose were collected and dried for 10 days in the laboratory (22). They were then soaked in water for 3 to $4 \mathrm{~h}$ every other day and maintained at $28^{\circ} \mathrm{C}$ for 60 to 90 days until pycnidia formed. Spore tendrils exuding from pycnidia were aseptically transferred to plates of PDA $+0.1 \%$ tartaric acid, and colonies were allowed to grow at 24 to $27^{\circ} \mathrm{C}$. This fungus was identified by the presence of characteristic alpha and beta conidia in the spore tendrils and by colony morphology (37).

For isolation of $M$. citri, mature leaves affected by greasy spot were surfacesterilized by dipping in $70 \%$ ethanol for 30 $\mathrm{s}$, rinsing with sterile distilled water, and placing them in $1 \%$ sodium hypochlorite for 5 to $10 \mathrm{~min}$ and rinsing thoroughly with sterile distilled water. The surface of the lesion was removed with a sterile scalpel, and small bits of mesophyll were transferred to PDA plates (45). Cultures were incubated for 10 to 14 days at 24 to $27^{\circ} \mathrm{C}$, and characteristic slow-growing, gray-green colonies were selected and transferred to fresh plates (36). Alternatively, decomposing leaves with mature pseudothecia of $M$. citri were collected from the grove floor, soaked for 10 to 15 min, blotted dry, and affixed to the lid of a petri plate containing $5 \%$ water agar using petroleum jelly to allow pseudothecia to eject ascospores onto the agar (23). Cultures were incubated overnight at 23 to $25^{\circ} \mathrm{C}$. Germinated ascospores were transferred to PDA $+0.1 \%$ tartaric acid. After formation of characteristic colonies, mycelial bits were transferred to fresh PDA.

Cultures of all pathogens obtained before 1998 were stored on PDA slants and transferred every 30 to 90 days to maintain them. Subsequently, all cultures were stored on filter paper (28). Mycelial bits were transferred to PDA plates placed next to a sterile $3 \times 3 \mathrm{~cm}$ piece of filter paper. Plates were incubated at 24 to $27^{\circ} \mathrm{C}$ until the filter paper was colonized. Then, the filters were lifted from the agar surface with sterile forceps, placed in a sterile coin envelope, and dried overnight in a laminar flow hood. Envelopes were placed in a closed plastic container with a desiccant and stored at $-20^{\circ} \mathrm{C}$ until needed. All cultures and their source and year of isolation are listed in Table 1.

Determination of $\mathbf{E D}_{\mathbf{5 0}}$ values. For all studies, commercial formulations of the products were used: azoxystrobin, Abound 2.08 EC (Syngenta Crop Protection, Greensboro, NC); pyraclostrobin, Headline 2.09 EC (BASF Corporation, Research Triangle Park, NC); and fenbuconazole, Enable 2F (Dow AgroSciences, Indianapolis, IN). These fungicides were diluted in sterile water and added to molten PDA at about $50^{\circ} \mathrm{C}$ to obtain final concentrations of $0,0.001,0.01,0.05,0.1,1.0,10$, and $100 \mu \mathrm{g}$ of active ingredient per ml. PDA was delivered into petri dishes with a Brickman Bottletop Dispenser (Brickman Instruments, Westbury, NY) using $20 \mathrm{ml}$ per $95 \times 15 \mathrm{~mm}$ diameter plate or $10 \mathrm{ml}$ per $65 \times 15 \mathrm{~mm}$ diameter dish.

Five isolates of each fungal species were evaluated for sensitivity to all three fungicides except that fenbuconazole was not tested with A. alternata or D. citri since it is not effective against those species $(13,37,49)$. Seed plates for each species were grown on PDA. Five-millimeterdiameter mycelial plugs were cut from the margin of colonies on the seed plates. These plugs were transferred to three or four replicate plates of each concentration of fungicide. Plates were maintained at ambient laboratory temperatures (23 to $25^{\circ} \mathrm{C}$ ) with about $12 \mathrm{~h}$ per day of fluorescent lighting. Colonies were grown until the no-fungicide plates were 50 to $75 \%$ covered with mycelium. Time required varied with the species and was 5 to 10 days with $C$. acutatum, A. alternata, and D. citri and 20 to 30 days with $M$. citri and E. fawcettii. Colony diameter was measured across two axes, averaged, and the diameter of the mycelial plug subtracted from the average. The percent inhibition was calculated in relation to the nofungicide controls. Each experiment was conducted twice.

The effective dose to reduce growth by $50 \%\left(\mathrm{ED}_{50}\right.$ value) for the three fungicides was calculated for each experiment with each isolate by fitting the dose response to a sigmoidal function. Each fungal species was evaluated in two experiments and all isolates tested each time. Thus, separate analyses for variances (ANOVAs) were conducted for each species. The effect of fungicide, isolate, and experiment plus all of the two-way interactions were investigated. Since in all cases, the variances were equal within fungal species, data were pooled and a response curve developed for each fungal species to each fungicide. The mean and range of $\mathrm{ED}_{50}$ values among isolates were calculated and presented.

Effect of SHAM on mycelial growth. Two isolates of each species were evaluated to determine the effect of salicylhydroxamic acid (SHAM) on growth of the fungi and their reaction to azoxystrobin 
and pyraclostrobin. SHAM was dissolved in methanol and added to molten PDA at $100 \mu \mathrm{g} / \mathrm{ml}$. Growth of each fungal species was evaluated as above using each fungicide at $0.0,0.01,0.1,1.0$, and $10 \mu \mathrm{g} / \mathrm{ml}$ in the presence or absence of SHAM. The isolates of each species used are given in Table 1. The experiment was conducted three times using four replicate dishes in each test. Since fungicides at low doses reversed the inhibition of mycelial growth by SHAM, percent inhibition and $\mathrm{ED}_{50}$ values could not be calculated. The effects of SHAM, isolate, fungicide concentration, and experiment were determined using ANOVAs of colony diameters.

Effect of SHAM and azoxystrobin on germination of conidia of A. alternata. The effects of azoxystrobin and SHAM on the conidial germination of A. alternata were also determined. Five isolates were used for these tests: Ran, LOR, SH, IMK, and EV (Table 1). Conidia were produced as described by Peever et al. (28). PDA plates with $0.0,0.01,0.1,1.0$, and 10 $\mu \mathrm{g} / \mathrm{ml}$ azoxystrobin with and without 100 $\mu \mathrm{g} / \mathrm{ml}$ SHAM were prepared as described above. Suspensions of conidia at 2,000 spores per milliliter were prepared and 0.1 $\mathrm{ml}$ spread on each petri dish. Conidia on dishes were incubated overnight at $25^{\circ} \mathrm{C}$. Four replicate dishes were used for each azoxystrobin-SHAM combination, and the experiment was repeated three times. One hundred conidia per petri dish were observed under a stereomicroscope to determine the percent germination.

$\mathrm{ED}_{50}$ values were calculated for each isolate-SHAM-experiment combination

Table 1. Fungal species and host, location, and dates of collection of isolates evaluated for sensitivity to fungicides

\begin{tabular}{|c|c|c|c|c|}
\hline Pathogen and isolates & No. of isolates used & Host $^{\mathrm{a}}$ & Location & Year \\
\hline \multicolumn{5}{|l|}{ Colletotrichum acutatum } \\
\hline CLR- IMK (7)*†b & 5 & Valencia sweet orange & Immokalee & 1999 \\
\hline OCO-ARC (1S)* & 5 & Navel sweet orange & Arcadia & 1999 \\
\hline GND & 5 & Navel sweet orange & $?$ & 1998 \\
\hline ALB IND & 5 & Valencia sweet orange & Indiantown & 2000 \\
\hline STL & 4 & Navel sweet orange & Frostproof & 1999 \\
\hline VTP-IND* & 5 & Navel sweet orange & Indiantown & 2000 \\
\hline SGR-FTP $* \dagger$ & 5 & Navel sweet orange & Frostproof & 1999 \\
\hline MRN-IND & 6 & Valencia sweet orange & Indiantown & 2000 \\
\hline RCO-IMK & 5 & Valencia sweet orange & Immokalee & 2000 \\
\hline SRL & 5 & Valencia sweet orange & Frostproof & 2000 \\
\hline LB & 1 & Navel sweet orange & La Belle & 1990 \\
\hline LB-4 & 1 & Navel sweet orange & La Belle & 1991 \\
\hline CS-1 & 1 & Valencia sweet orange & Ft. Pierce & 1993 \\
\hline PS-1 & 1 & Navel sweet orange & Lake Placid & 1993 \\
\hline PS-2 & 1 & Valencia sweet orange & Lake Placid & 1993 \\
\hline Coca Cola & 1 & Navel sweet orange & Indiantown & 1993 \\
\hline Maran-91 & 1 & Valencia sweet orange & Indiantown & 1991 \\
\hline SM-3* & 1 & Valencia sweet orange & Lake Placid & 1993 \\
\hline LP-2 & 1 & Valencia sweet orange & Lake Placid & 1991 \\
\hline MAYO & 1 & Navel sweet orange & Vero Beach & 1993 \\
\hline \multicolumn{5}{|l|}{ Alternaria alternata } \\
\hline WP-MIL & 5 & Minneola tangelo & West Palm Bch. & 1996 \\
\hline Ran*† & 5 & Sunburst tangerine & Immokalee & 1997 \\
\hline LOR* & 4 & Sunburst tangerine & Lorida & 1997 \\
\hline $\mathrm{SH}^{*}$ & 5 & Minneola tangelo & Polk City & 1996 \\
\hline FM & 3 & Minneola tangelo & Fort Meade & 1996 \\
\hline CPI & 4 & Murcott tangor & Immokalee & 1996 \\
\hline $\mathrm{EV} *$ & 4 & Minneola tangelo & Lake Alfred & 1996 \\
\hline SWAMP-1 & 1 & Minneola tangelo & Polk City & $?$ \\
\hline IMK*† & 5 & Minneola tangelo & Immokalee & 1997 \\
\hline VB & 5 & Grapefruit & Vero Beach & 1997 \\
\hline AR & 5 & Sunburst tangerine & Arcadia & 1997 \\
\hline Re-ISO & 1 & Orlando tangelo & Winter Haven & $?$ \\
\hline IRA & 1 & Minneola tangelo & $?$ & $?$ \\
\hline $10 \mathrm{AR}$ & 2 & Minneola tangelo & $?$ & $?$ \\
\hline \multicolumn{5}{|l|}{ Elsinoe fawcettii } \\
\hline Ft. Pierce & 4 & Temple tangor & Ft. Pierce & 2001 \\
\hline IMK Temple & 7 & Temple tangor & Immokalee & 2001 \\
\hline Con-Lal & 2 & Calamondin & Orange Co. & 2001 \\
\hline Duda-IMK-TEMPLE & 5 & Temple tangor & Immokalee & 2001 \\
\hline STL-TEM & 1 & Temple tangor & Frostproof & 2001 \\
\hline SS-IMK TEM & 3 & Temple tangor & Immokalee & 2001 \\
\hline LKPCD-TEM & 2 & Temple tangor & Lake Placid & 2001 \\
\hline TBL-LA TEM & 5 & Temple tangor & Lake Alfred & 2001 \\
\hline EUS MUR & 2 & Murcott tangor & Eustis & 2001 \\
\hline EUR MUR LV-1 & 1 & Murcott tangor & Eustis & 2001 \\
\hline SWFRC-IMK-TEM & 1 & Temple tangor & Immokalee & 2001 \\
\hline SWFRC-MUR-LV-1 & 2 & Murcott tangor & Immokalee & 2001 \\
\hline Ft. Meade & 2 & Grapefruit & Ft. Pierce & 2001 \\
\hline
\end{tabular}

${ }^{a}$ Sweet orange $=$ Citrus sinensis, tangelo $=C$. paradisi $\times$ C. reticulata, tangor $=C$. sinensis $\times C$. reticulata, tangerine or mandarin $=C$. reticulata, grapefruit $=C$. paradisi, calamondin $=C$. limonia $\times$ Fortunella sp.?, Tahiti lime $=$ C. latifolia, Volkamer lemon $=C$. volkameriana, rough lemon $=C$. jambhiri, citrange $=$ Poncirus trifoliata $\times$ C. sinensis.

$\mathrm{b} *$ Indicates isolates used for determination of the effective dose to reduce growth by $50 \%\left(\mathrm{ED}_{50}\right)$ for each species; where more than one isolate is listed, only one from that location was used for the $\mathrm{ED}_{50}$ determination; ${ }^{\dagger}$ indicates isolates used for determination of the effect of salicylhydroxamic acid (SHAM) on the $\mathrm{ED}_{50}$ values for mycelial growth.

c Isolate used for all pyraclostrobin assays to replace "Felsmere" after it was lost. 
using sigmoidal functions. $\mathrm{ED}_{50}$ values for azoxystrobin with SHAM were based on comparison with the SHAM plates with no fungicide. Then $\mathrm{ED}_{50}$ values were subjected to ANOVAs to determine the effects of isolate, addition of SHAM, and experiment on the sensitivity of conidial germination.

Range of sensitivity. A discriminatory concentration near the $\mathrm{ED}_{50}$ value was selected for each fungicide-species combination. The 50 to 62 isolates collected for each fungal species were evaluated at that concentration in a similar manner to that described above. All experiments were conducted twice and results averaged to determine the percent inhibition of each isolate for the fungicide tested. The range and the coefficients of variation were calculated for each fungicide-fungal species combination.

\section{RESULTS}

Determination of $\mathbf{E D}_{\mathbf{5 0}}$ values. In the analysis of variance of the response of different pathogens to fungicides, the effect of fungicide was highly significant (Table 2). The effect of isolate as well as the fungicide $\times$ isolate interaction was significant for E. fawcettii, D. citri, and M. citri, but not for the other two species. There was no significant effect of experiment and no significant interaction of experiment with other factors (Table 2) Since variances were equal, data from different isolates and experiments were pooled to calculate a mean $\mathrm{ED}_{50}$ for each pathogen-fungicide combination using sigmoidal functions (Figs. 1 to 3), and the means and ranges for different isolates were calculated (Table 3 ). The regression coefficients ranged from 0.91 to 0.99 , and all were highly significant.

Table 1. (continued)

\begin{tabular}{|c|c|c|c|c|}
\hline Pathogen and isolates & No. of isolates used & Host $^{\mathbf{b}}$ & Location & Year \\
\hline \multicolumn{5}{|c|}{ Elsinoe fawcettii (continued) } \\
\hline Manatee Co. & 3 & Temple tangor & Manatee Co. & 2001 \\
\hline Lef GF & 1 & Grapefruit & Bowling Green & ? \\
\hline Lef-FF-1 & 1 & Grapefruit & Bowling Green & $?$ \\
\hline Brigg & 2 & Grapefruit & Babson Park & 2003 \\
\hline IRREC-MUR & 2 & Murcott tangor & Ft. Pierce & 2001 \\
\hline SS IMK Lime & 2 & Tahiti lime & Immokalee & 2001 \\
\hline Lefond* & 1 & Grapefruit & Bowling Green & 2000 \\
\hline Navarro & 4 & Grapefruit & Frostproof & 2003 \\
\hline $\mathrm{CC}-3$ & 1 & Volkamer lemon & Indiantown & 1990 \\
\hline $\mathrm{R}-31$ & 1 & Temple tangor & Lake Placid & 1991 \\
\hline Roesseto Bent. R & 1 & Grapefruit & Ona & 2003 \\
\hline May & 2 & Grapefruit & Avon Park & 2003 \\
\hline Volk* & 1 & Volkamer lemon & Indiantown & 1990 \\
\hline RL & 1 & Rough lemon & Lake Alfred & $?$ \\
\hline Cal-WH-1 & 1 & Calamondin & Winter Haven & 2002 \\
\hline Hunt Bent R & 1 & Temple tangor & Frostproof & 2003 \\
\hline Carrizo* & 1 & Carrizo citrange & Lake Alfred & 1996 \\
\hline $\mathrm{SCSK}^{\dagger}$ & 1 & SunChaShaKat mandarin & Sebring & 1992 \\
\hline Hastings* & 1 & Grapefruit & Hastings & 1991 \\
\hline Scott*i & 1 & Temple tangor & Davenport & 1990 \\
\hline \multicolumn{5}{|l|}{ Diaporthe citri } \\
\hline East LW & 5 & Grapefruit & Lake Wales & 2003 \\
\hline Lake Wales & 5 & Grapefruit & Lake Wales & 2003 \\
\hline SS-29 & 7 & Grapefruit & Immokalee & 2003 \\
\hline Ft-Pierce-SW & 4 & Sweet orange & Ft. Pierce & 2003 \\
\hline Budwood Flame & 4 & Grapefruit & Immokalee & 2002 \\
\hline Immokalee-Temple & 1 & Temple tangor & Immokalee & 2002 \\
\hline Ft Pierce-Temple & 5 & Temple tangor & Fort Pierce & 2003 \\
\hline PC Ft Pierce & 5 & Sweet orange & Fort Pierce & 2003 \\
\hline Lefond & 5 & Grapefruit & Bowling Green & 2001 \\
\hline Berry & 5 & Grapefruit & LaBelle & 2002 \\
\hline Berkovitz & 2 & Grapefruit & Frostproof & 2001 \\
\hline Ever Glades & 5 & Grapefruit & Immokalee & 2002 \\
\hline Lake Placid & 4 & Sweet orange & Lake Placid & 2003 \\
\hline STL & 6 & Temple tangor & Frostproof & 2003 \\
\hline Ser-2-2*广 & 1 & Grapefruit & Lake Alfred & 1995 \\
\hline $\mathrm{D}-1 *^{\dagger}$ & 1 & Sweet orange & Dundee & 2000 \\
\hline JMP-2* & 1 & Grapefruit & Bowling Green & 2000 \\
\hline P-94* & 1 & Grapefruit & Lake Alfred & 1991 \\
\hline Nova-2* & 1 & Grapefruit & Lake Alfred & 1997 \\
\hline \multicolumn{5}{|l|}{ Mycosphaerella citri } \\
\hline SLT & 6 & Temple tangor & Frostproof & $?$ \\
\hline FTP & 6 & Grapefruit & Frostproof & 2000 \\
\hline MC-IMK-SS $* \dagger$ & 5 & Grapefruit & Immokalee & 2000 \\
\hline Conserve* ${ }^{\dagger}$ & 5 & Grapefruit & Orange Co. & 2001 \\
\hline SS-IMK & 4 & Grapefruit & Immokalee & 2001 \\
\hline Lef- $1 *$ & 1 & Sweet orange & Bowling Green & 2001 \\
\hline MC LA & 8 & Grapefruit & Lake Alfred & 2000 \\
\hline MC Lef G & 4 & Grapefruit & Bowling Green & 2001 \\
\hline Felsmere* & 1 & Navel sweet orange & Felsmere & 1996 \\
\hline PREC & 4 & Grapefruit & Ft. Pierce & 2001 \\
\hline APR-EC & 4 & Grapefruit & Ft. Pierce & 2001 \\
\hline Duda & 5 & Grapefruit & Immokalee & 2001 \\
\hline Raley & 6 & Valencia sweet orange & Lake Placid & 2001 \\
\hline $\mathrm{EV}^{*}$ & 2 & Minneola tangelo & Lake Alfred & ? \\
\hline $\mathrm{ARC} * \mathrm{c}$ & 1 & Sweet orange & Arcadia & 1997 \\
\hline
\end{tabular}


E. fawcettii and D. citri were the most sensitive to azoxystrobin, and C. acutatum and $M$. citri had slightly higher $\mathrm{ED}_{50}$ values (Table 3). Mycelial growth of A. alternata was insensitive to azoxystrobin. The $\mathrm{ED}_{50}$ values for all five species were lower for pyraclostrobin than for azoxystrobin. The sensitivity of isolates of E. fawcettii and $M$. citri to fenbuconazole was similar to their sensitivity to pyraclostrobin (Table 3, Fig. 3). Fenbuconazole was more active against $C$. acutatum than was azoxystrobin, but less active than pyraclostrobin.

Effect of SHAM on mycelial growth. ANOVAs indicated that fungicide concentration and SHAM had significant effects on the colony diameter of all five species of fungi. In all combinations of fungicidefungal species, except for the E. fawcettiipyraclostrobin pair, the $\mathrm{SHAM} \times$ fungicide interaction was significant. Thus, the response to fungicide concentration is altered by SHAM, but it does not obviously increase the sensitivity of the fungi to azoxystrobin or pyraclostrobin (Fig. 4).

In fact, addition of low rates of fungicide appeared to reverse the inhibition of mycelial growth by SHAM (Fig. 4). With all species of fungi, colony diameter was slightly greater in the presence of pyraclostrobin at $0.01 \mu \mathrm{g} / \mathrm{ml}$ plus SHAM than with SHAM alone. In the case of $M$. citri, colony diameter in the presence of 10 $\mu \mathrm{g} / \mathrm{ml}$ pyraclostrobin was still greater than with SHAM alone. The effects were less dramatic with azoxystrobin and were noted only with E. fawcettii, D. citri, and $M$. citri. With $D$. citri, addition of $0.01 \mu \mathrm{g} / \mathrm{ml}$ azoxystrobin to dishes with SHAM had three times greater colony diameter than with SHAM alone.

Sensitivity of conidia of A. alternata to azoxystrobin and SHAM. The ANOVA indicated that SHAM had no effect on the sensitivity of conidial germination to azoxystrobin. Neither isolate nor experiment had significant effects in the analysis. The mean $\mathrm{ED}_{50}$ value for all isolates without SHAM was $0.12 \mu \mathrm{g} / \mathrm{ml}$ and with SHAM was $0.06 \mu \mathrm{g} / \mathrm{ml}$. These values are much lower than the values for mycelial growth (Table 3 ).

Range of fungicide sensitivity. A discriminatory concentration was selected based on the $\mathrm{ED}_{50}$ values of the five iso-

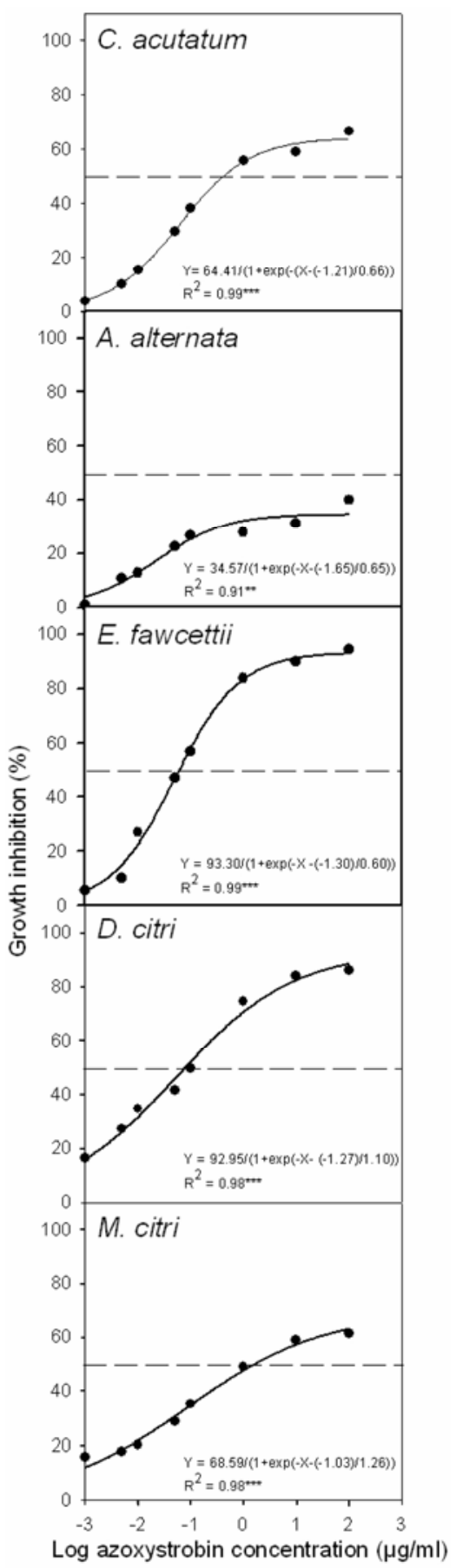

Fig. 1. Inhibition of mycelial growth of Colletotrichum acutatum, Alternaria alternata, Elsinoe fawcettii, Diaporthe citri, and Mycosphaerella citri by different concentrations of azoxystrobin.

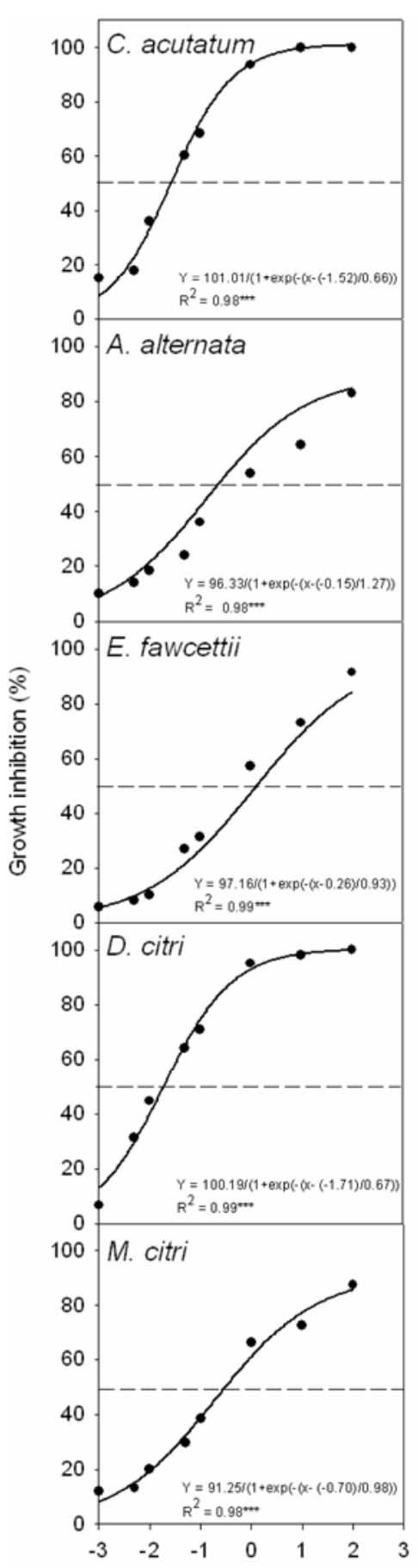

Log pyraclostrobin concentration $(\mu \mathrm{g} / \mathrm{ml})$

Fig. 2. Inhibition of mycelial growth of Colletotrichum acutatum, Alternaria alternata, Elsinoe fawcettii, Diaporthe citri, and Mycosphaerella citri by different concentrations of pyraclostrobin.

Table 2. Analysis of variance of the effect of the concentration of azoxystrobin, pyraclostrobin, and fenbuconazole on the mycelial growth of five fungal pathogens of citrus

\begin{tabular}{|c|c|c|c|c|c|c|}
\hline \multirow{2}{*}{$\begin{array}{l}\text { Sources } \\
\text { of variation }\end{array}$} & \multirow[b]{2}{*}{ df } & \multicolumn{5}{|c|}{$P$ values } \\
\hline & & Colletotrichum acutatum & Alternaria alternata & Elsinoe fawcettii & Diaporthe citri & Mycosphaerella citri \\
\hline Fungicide (F) & $2(\text { or } 1)^{\mathrm{a}}$ & $\leq 0.001^{\mathrm{b}}$ & $\leq 0.001$ & $\leq 0.001$ & $\leq 0.001$ & $\leq 0.001$ \\
\hline Isolate (I) & 4 & 0.27 & 0.59 & $\underline{0.01}$ & $\underline{0.001}$ & $\underline{0.006}$ \\
\hline Experiment $(\mathrm{E})$ & 1 & 0.68 & 0.61 & $\overline{0.23}$ & 0.30 & 0.21 \\
\hline $\mathrm{F} \times \mathrm{I}$ & 8 (or 4) & 0.61 & 0.61 & $\leq 0.001$ & $\underline{0.002}$ & $\underline{0.03}$ \\
\hline $\mathrm{F} \times \mathrm{E}$ & 2 (or 1$)$ & 0.47 & 0.62 & 0.20 & 0.71 & 0.57 \\
\hline $\mathrm{I} \times \mathrm{E}$ & 4 & 0.84 & 0.50 & 0.44 & 0.58 & 0.70 \\
\hline
\end{tabular}

a Number in parentheses for A. alternata and D. citri.

b Significant effects are underlined. 
lates (Table 3) and used to test the field isolates. The range of sensitivity of $C$. acutatum and the coefficient of variation (CV) of $C$. acutatum was low for both strobilurin fungicides (Table 3), and most isolates fell into one or two sensitivity categories (Figs. 5 and 6). With A. alternata and $D$. citri, there were a few isolates that were quite tolerant to azoxystrobin and some that were relatively sensitive

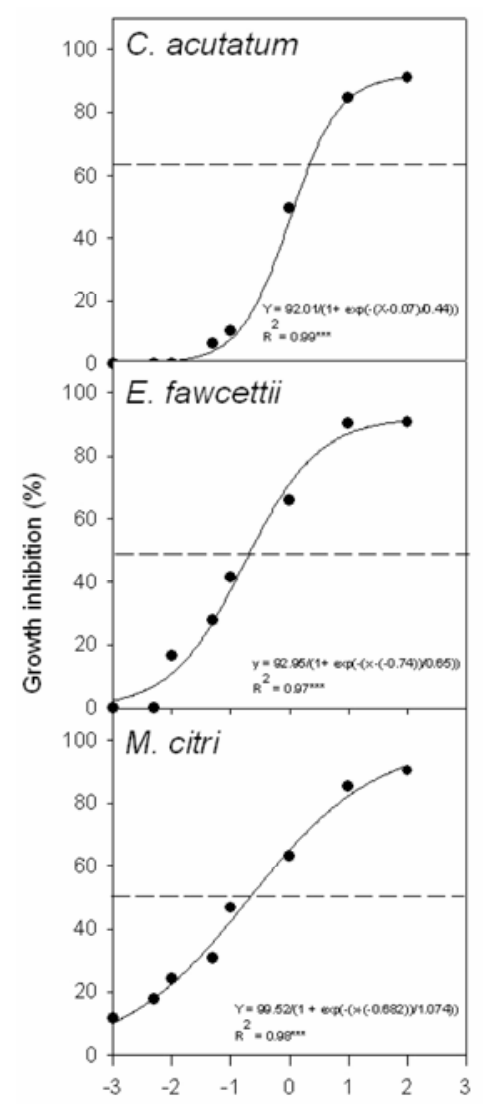

Log fenbuconazole concentration $(\mu \mathrm{g} / \mathrm{ml})$

Fig. 3. Inhibition of mycelial growth of Colletotrichum acutatum, Elsinoe fawcettii, and Mycosphaerella citri by different concentrations of fenbuconazole.
(Fig. 5). With the other pathogens, the number of isolates falling in any given category, e.g., 40 to $60 \%$ inhibition, was similar to the number in other categories. The response of the same isolates to pyraclostrobin was similar, but the ranges and $\mathrm{CV}$ were generally lower than for azoxystrobin (Table 3). There were a few isolates of A. alternata that were especially sensitive or tolerant to pyraclostrobin (Fig. 5). Single isolates of E. fawcettii and a few $M$. citri were especially insensitive to this fungicide. Other than those isolates, most fell into a continuum in their response to pyraclostrobin.

With fenbuconazole, the ranges of sensitivity and CVs were generally higher than with the strobilurin fungicides (Table 3). There were several isolates of $M$. citri that were especially sensitive to fenbuconazole (Fig. 7).

\section{DISCUSSION}

In this study, the $\mathrm{ED}_{50}$ values and the ranges of sensitivity of the five principal foliar fungal pathogens of citrus to azoxystrobin, pyraclostrobin, and fenbuconazole were established. These fungicides were registered for use on Florida citrus in recent years. Both the strobilurin and SBI fungicides are prone to development of resistance. We now have established discriminatory concentrations for each pathogen-fungicide combination based on mycelial growth of isolates recovered prior to the use of these products in groves. When control failures occur in groves, isolates obtained from those groves can be compared with baselines now established.

In general, the citrus pathogens were much less sensitive than other fungi tested for sensitivity to strobilurin fungicides. In our study, the $\mathrm{ED}_{50}$ values for mycelial growth of citrus pathogens to azoxystrobin ranged from $0.06 \mu \mathrm{g} / \mathrm{ml}$ for $E$. fawcettii to greater than $100 \mu \mathrm{g} / \mathrm{ml}$ for A. alternata. In contrast, the $\mathrm{ED}_{50}$ values for conidial germination for azoxystrobin for Plasmopara viticola on grapes ranged from 0.05 to 0.94 $\mu \mathrm{g} / \mathrm{ml}$ (47) and for Uncinula necator ranged from 0.0037 to $0.028 \mu \mathrm{g} / \mathrm{ml}$ (48). However, both of these organisms are obligate biotrophs, and the sensitivity of these pathogens to azoxystrobin was based primarily on spore germination rather than mycelial growth. In studies based on mycelial growth in vitro, results were more comparable to those obtained with citrus pathogens $(5,25)$. The $\mathrm{ED}_{50}$ values of Venturia inaequalis isolates to kresoxim methyl as determined by mycelial growth in vitro ranged from 0.11 to $0.75 \mu \mathrm{g} / \mathrm{ml}$ (25). With Colletotrichum graminicola, the $\mathrm{ED}_{50}$ values in relation to azoxystrobin were 0.01 to 0.1 for sensitive isolates (16). The sensitivity of pathogens of other crops to pyraclostrobin has not been reported.

The citrus pathogens were much less sensitive to fenbuconazole than was Monilinia oxycocci, a cranberry pathogen (21). The $\mathrm{ED}_{50}$ values of sensitive isolates of $M$. oxycocci were about 0.0001 to $0.001 \mu \mathrm{g} / \mathrm{ml}$ compared to 0.24 to 1.49 for citrus pathogens. Cladosporium caryigenum, the cause of pecan scab, had $\mathrm{ED}_{50}$ values of 0.19 to $0.30 \mu \mathrm{g} / \mathrm{ml}$ (33), which were more similar to those found for citrus pathogens.

Fungicide sensitivity to strobilurin fungicides determined in vitro may not be an accurate reflection of their sensitivity to these products in vivo $(4-6,25,26)$. Many fungi respond to $\mathrm{Q}_{0} \mathrm{I}$ fungicides by expression of alternative respiration, a pathway that avoids electron transport through the target site of the $\mathrm{Q}_{0} \mathrm{I}$ fungicides, cytochrome $b$. Azoxystrobin did not inhibit growth of A. alternata by $50 \%$ even at 100 $\mu \mathrm{g} / \mathrm{ml}$. Thus, fungi attacking citrus could be using alternative respiration to avoid effects of the $\mathrm{Q}_{\mathrm{o}} \mathrm{I}$ fungicides on the cytochrome $b$ system in vitro, or mycelium may not take up these fungicides well. Alternative respiration is usually not active in fungi in the plant $(4,5,15)$, and thus, many fungi are more sensitive in vivo than in vitro. Salicylhydroxamic acid (SHAM),

Table 3. Mean effective dose to reduce growth by $50 \%\left(\mathrm{ED}_{50}\right.$ value) for each fungicide-species combination, selected discriminatory concentration, and range and coefficient of variation (CV) for the 50 to 62 isolates evaluated at that concentration

\begin{tabular}{|c|c|c|c|c|}
\hline \multirow{2}{*}{$\begin{array}{l}\text { Fungicide } \\
\text { Fungal pathogen } \\
\end{array}$} & \multirow[b]{2}{*}{$\mathrm{ED}_{50}(\mu \mathrm{g} / \mathrm{ml})^{\mathrm{a}}$} & \multirow{2}{*}{$\begin{array}{c}\text { Selected discriminatory } \\
\text { concentration }\end{array}$} & \multicolumn{2}{|c|}{ Field isolates inhibition (\%) } \\
\hline & & & Range & $\mathrm{CV}(\%)$ \\
\hline \multicolumn{5}{|l|}{ Azoxystrobin } \\
\hline Colletotrichum acutatum & $0.40(0.09-0.79)$ & 1.0 & 23.18 & 8.36 \\
\hline Alternaria alternata & $>100($ all > 100 $)$ & 100.0 & 64.18 & 39.71 \\
\hline Elsinoe fawcettii & $0.06(0.03-0.45)$ & 0.1 & 69.84 & 25.04 \\
\hline Diaporthe citri & $0.08(0.03-0.45)$ & 0.1 & 60.40 & 28.35 \\
\hline Mycosphaerella citri & $1.62(0.37-4.2)$ & 1.0 & 45.82 & 30.11 \\
\hline \multicolumn{5}{|l|}{ Pyraclostrobin } \\
\hline C. acutatum & $0.029(0.01-0.034)$ & 0.01 & 18.36 & 7.30 \\
\hline A. alternata & $0.87(0.37-1.58)$ & 10.0 & 46.04 & 22.11 \\
\hline E. fawcettii & $0.62(0.21-1.31)$ & 0.1 & 53.92 & 32.17 \\
\hline D. citri & $0.019(0.003-0.059)$ & 0.01 & 31.05 & 19.16 \\
\hline M. citri & $0.03(0.02-0.89)$ & 0.1 & 52.49 & 31.70 \\
\hline \multicolumn{5}{|l|}{ Fenbuconazole } \\
\hline C. acutatum & $1.01(0.85-1.26)$ & 0.1 & 36.81 & 31.64 \\
\hline E. fawcettii & $0.22(0.11-0.46)$ & 1.0 & 49.00 & 20.84 \\
\hline M. citri & $0.21(0.13-0.75)$ & 0.1 & 59.96 & 55.02 \\
\hline
\end{tabular}

${ }^{a}$ Average and range in parentheses of five isolates of each species and two experiments with each. 
which blocks alternative respiration, can be incorporated into the medium to determine the sensitivity of fungi to $\mathrm{Q}_{\mathrm{O}} \mathrm{I}$ fungicides $(5,25)$. However, with the citrus pathogens, SHAM itself was quite inhibitory. SHAM did not increase the sensitivity of mycelial growth of any of the citrus pathogens to the strobilurins. Thus, there is no indication that mycelium of these fungi is utilizing alternative respiration to avoid the toxic effects of the strobilurin fungicides.

Spore germination may be more sensitive than mycelial growth to the inhibitory effects of strobilurin fungicides $(26,27)$. In the current study, mycelial growth of $A$. alternata was rather insensitive to this fungicide, but the $\mathrm{ED}_{50}$ for spore germination was much lower. As with mycelial growth, the addition of SHAM did not increase the activity of azoxystrobin against A. alternata. Pasche et al. (27) found that SHAM did not inhibit spore germination of $A$. solani from potatoes; but they used SHAM in all of the evaluations and thus did not evaluate the effect of this chemical on the sensitivity of the fungus to azoxystrobin.
Despite the comparatively low activity of strobilurins and fenbuconazole against mycelial growth of most citrus fungal pathogens, these fungicides are moderately to highly effective for control of most diseases (37). Azoxystrobin and trifloxystrobin were effective for control of PFD but generally were less active than the benzimidazoles for this disease $(26,27,38)$. They are recommended in Florida in combination with contact fungicides for improved control and for resistance management (37). Fenbuconazole has not been evaluated for PFD control, but other SBI

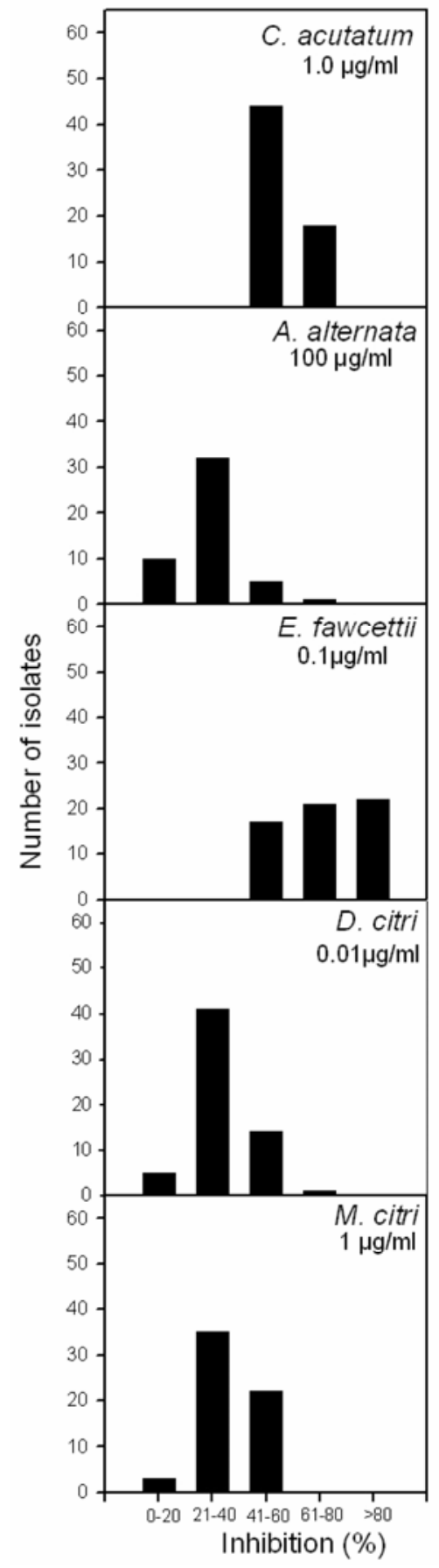

Fig. 5. Range of isolate sensitivity of Colletotrichum acutatum, Alternaria alternata, Elsinoe fawcettii, Diaporthe citri, and Mycosphaerella citri to azoxystrobin.
Fig. 4. Effect of salicylhydroxamic acid (SHAM) on the activity of azoxystrobin and pyraclostrobin on mycelial growth of Colletotrichum acutatum, Alternaria alternata, Elsinoe fawcettii, Diaporthe citri, and Mycosphaerella citri at different concentrations of fungicide. * Indicates that colony diameter is significantly lower with $100 \mathrm{ppm}$ of SHAM than in its absence according to LSD, $P=0.05$.

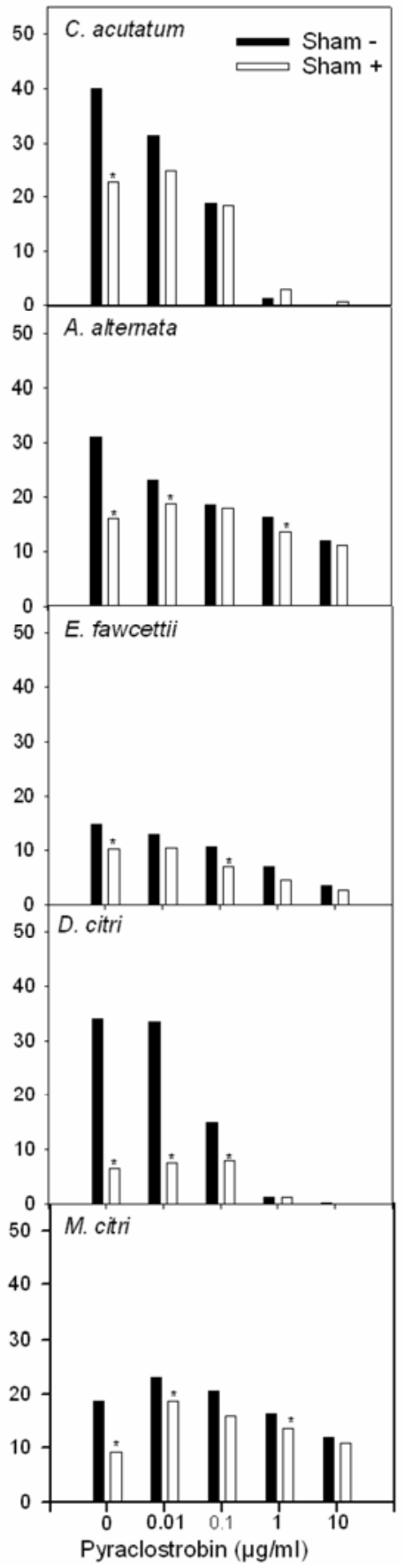

1192 Plant Disease /Vol. 89 No. 11 
fungicides are moderately active against PFD (30). In the field, azoxystrobin and pyraclostrobin are highly effective for control of Alternaria brown spot $(8,9,11,36)$. This contrasts sharply with the high $\mathrm{ED}_{50}$ values observed for these fungicides against mycelial growth of $A$. alternata in vitro. The activity of strobilurins in the field is due to their ability to inhibit spore germination. Pyraclostrobin, azox-

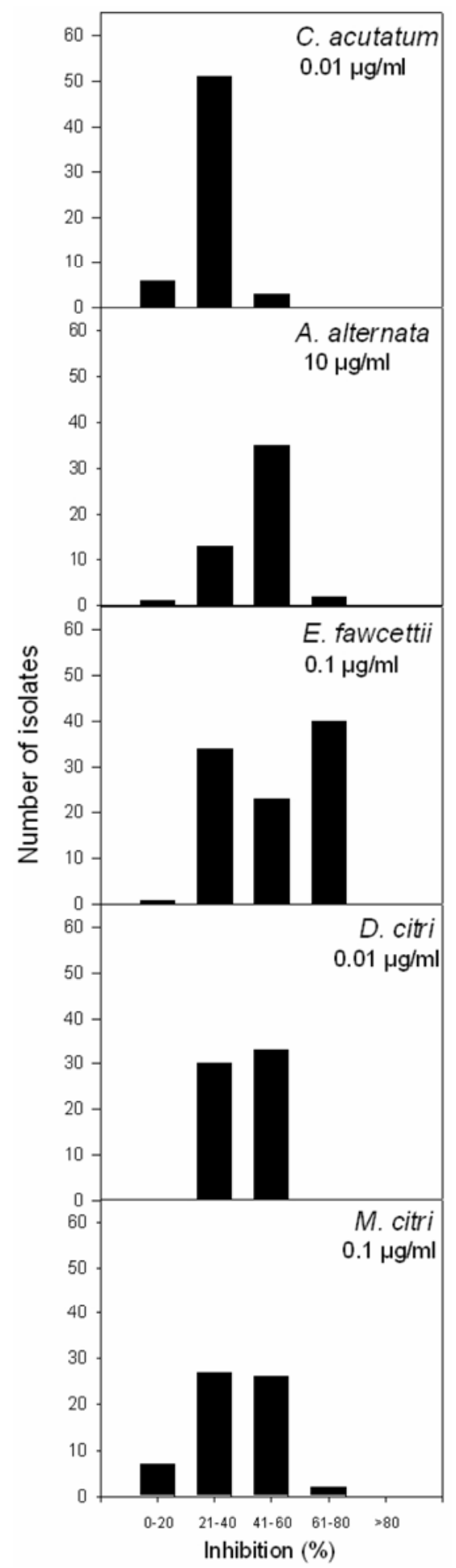

Fig. 6. Range of isolate sensitivity of Colletotrichum acutatum, Alternaria alternata, Elsinoe fawcettii, Diaporthe citri, and Mycosphaerella citri to pyraclostrobin. ystrobin, and fenbuconazole are all highly effective against citrus scab under field conditions $(2,10,38,49)$. Azoxystrobin and fenbuconazole have good preventive activity against scab infection and also proved effective as eradicants in greenhouse studies (14). Azoxystrobin and pyraclostrobin are moderately to highly effective for melanose control used alone or in programs with copper fungicides $(1,49)$. Azoxystrobin had good preventive activity in greenhouse tests but was not effective as a postinfectional application (14). Fenbuconazole is relatively ineffective for melanose control in the field $(13,49)$. In vitro, pyraclostrobin was more active against $D$. citri than was azoxystrobin. Azoxystrobin, pyraclostrobin, and fenbuconazole are effective for control of greasy spot in the field, especially when used in combination with petroleum oil $(12,35)$. Fenbuconazole was also very effective in reducing the epiphytic growth of $M$. citri and in reducing disease severity $(7,24)$.

The $\mathrm{ED}_{50}$ and discriminatory values determined in this study should be useful for detection of resistance to these fungicides in most cases. When isolates resistant to strobilurin fungicides occur, they usually tolerate high levels of fungicide, often

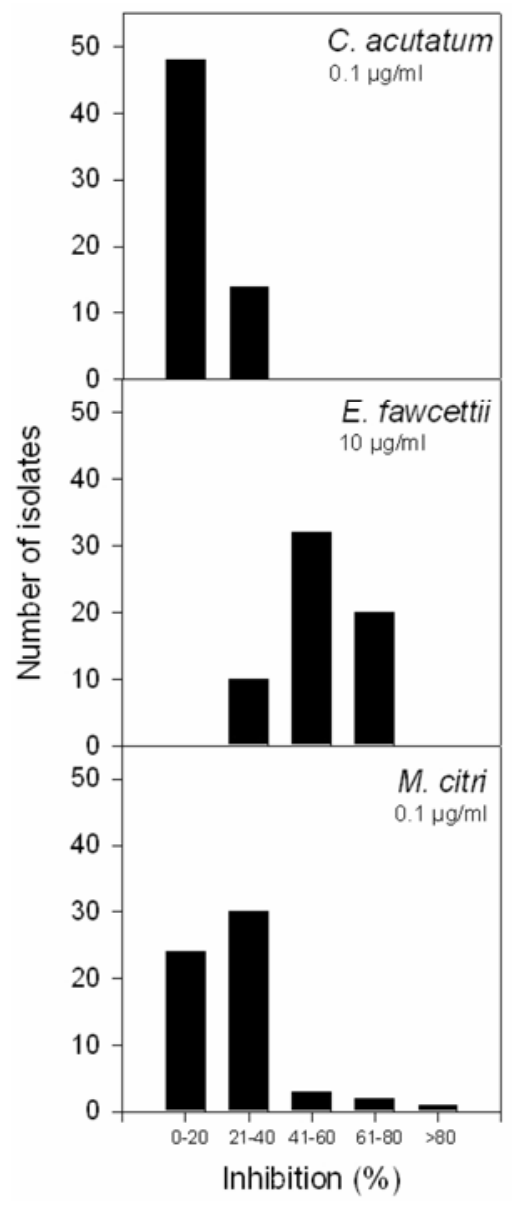

Fig. 7. Range of isolate sensitivity of Colletotrichum acutatum, Elsinoe fawcettii, and Mycosphaerella citri to fenbuconazole. greater than $10 \mu \mathrm{g} / \mathrm{ml}$ (5). Thus, the situation should be comparable to resistance to benzimidazole fungicides in E. fawcettii and $M$. citri, where isolates with resistance were readily detected $(43,44)$. Ma et al. (18) also found that resistant isolates of Alternaria spp. tolerated high levels of azoxystrobin even though the mutation was different from the one commonly found. However, Pasche et al. (27) found that $A$. solani isolates on potatoes can develop an insensitivity to azoxystrobin and that the average $\mathrm{ED}_{50}$ can increase steadily with continued use. If decreases in sensitivity of citrus pathogens are incremental, the development of resistance may be more difficult to detect.

In the case of the A. alternataazoxystrobin combination, the discriminatory concentration of $100 \mu \mathrm{g} / \mathrm{ml}$ is probably not useful for detection of resistance in future studies. Since spore germination is much more sensitive than mycelial growth, resistance to azoxystrobin will be much more easily detected using conidia. The range of sensitivity of a large number of isolates remains to be determined. However, use of spores for assessment of fungicide sensitivity with some of the other species may be difficult. Conidia of $D$. citri require weeks to produce (22), $M$. citri produces few conidia in culture or in nature, and production of conidia with $E$. fawcettii is laborious. Only $C$. acutatum produces abundant conidia rapidly in culture.

Resistance to fenbuconazole could also be difficult to detect. With the SBI fungicides, resistance usually occurs as incremental shifts in tolerance in the population $(21,33)$. Thus, to detect resistance shifts requires determination of the $\mathrm{ED}_{50}$ values from relatively large numbers of isolates. So the situation may be comparable to the benzimidazole-C. acutatum relationship, where resistance would be difficult to detect (30). Large numbers of isolates will be needed to assess resistance levels of populations of these pathogens.

In most cases, evaluations of large numbers of isolates of citrus fungal pathogens can be difficult and time-consuming. A. alternata isolates can be collected at any time of year and grow rapidly, but isolates must be evaluated for pathogenicity since saprophytes of the same species are common on citrus (32). C. acutatum is readily isolated from infected petals but is much more difficult to recover from vegetative tissues (3), and thus, larger numbers of isolates can only be collected during epidemic years at bloom time. $M$. citri and $E$. fawcettii can be isolated relatively easily at most times during the year. However, both are very slow growing and require weeks to evaluate resistance. $D$. citri grows more rapidly but can be consistently isolated only from twigs (22), which requires weeks. Despite the difficulties, methods are available to collect sufficient isolates to 
evaluate control failures to determine whether they are due to resistance development or to other problems. The recent development of the spiral gradient dilution for use with fungi (17) should be helpful in evaluating the sensitivity of large numbers of isolates, but collection of isolates will still be time-consuming.

\section{ACKNOWLEDGMENTS}

This research was partially supported by Syngenta Crop Protection, Inc., BASF Corporation, and by Project No. 013-16P of the Florida Citrus Production Research Advisory Council "Biology and Control of Fungal Diseases of Fruit and Foliage." We gratefully acknowledge the excellent technical assistance of C. L. Geanangel and Li Zhang.

\section{LITERATURE CITED}

1. Agostini, J. P., Tesoriero, A. J., and Timmer, L. W. 2002. Evaluation of fungicides for control of melanose on grapefruit, 2001. American Phytopathological Society, St. Paul, MN. Fungic. Nematicide Tests (online) Report 57:M01.DOI.10.1094/FN57.

2. Agostini, J. P., Tesoriero, A. J., and Timmer, L. W. 2002. Evaluation of products for the control of citrus scab on Temple tangors, 2001. American Phytopathological Society, St. Paul, MN. Fungic. Nematicide Tests (online) Report 57:M10.DOI.10.1094/FN57.

3. Agostini, J. P., and Timmer, L. W. 1994. Population dynamics and survival of strains of $\mathrm{Col}$ letotrichum gloeosporioides on citrus in Florida. Phytopathology 84:420-425.

4. Avila-Adame, C., and Koller, W. 2003. Characterization of spontaneous mutants of Magnaporthe grisea expressing stable resistance to the $\mathrm{Q}_{0}$-inhibiting fungicides. Curr. Genet. 42:332-338.

5. Avila-Adame, C., Olaya, G., and Koller, W. 2003. Characterization of Colletotrichum graminicola isolates resistant to strobilurinrelated $\mathrm{Q}_{0} \mathrm{I}$ fungicides. Plant Dis. 87:14261432.

6. Bartlett, D. W., Clough, J. M., Godwin, J. R., Hall, A. A., Hamer, M., and Parr-Dobrzanski, B. 2002. The strobilurin fungicides. Pest Manag. Sci. 58:649-662.

7. Bhatia, A., Tesoriero, A. J., and Timmer, L. W. 2002. Evaluation of fungicides for control of greasy spot on grapefruit, 2000-2001. American Phytopathological Society, St. Paul, MN. Fungic. Nematicide Tests (online) Report 57:M02.DOI.10.1094/FN57.

8. Bhatia, A., Tesoriero, A. J., and Timmer, L. W. 2002. Evaluation of fungicides for control of Alternaria brown spot on Murcotts, 2001. American Phytopathological Society, St. Paul, MN. Fungic. Nematicide Tests (online) Report 57:M06.DOI.10.1094/FN57.

9. Bhatia, A., Tesoriero, A. J., and Timmer, L. W. 2002. Evaluation of fungicides for control of Alternaria brown spot on Murcotts, 2000. American Phytopathological Society, St. Paul, MN. Fungic. Nematicide Tests (online) Report 57:M07.DOI.10.1094/FN57.

10. Bhatia, A., and Timmer, L. W. 2003. Evaluation of products for control of citrus scab on Temple tangor, 2002. American Phytopathological Society, St. Paul, MN. Fungic. Nematicide Tests (online) Report 58:MO04.DOI.10.1094/FN58.

11. Bhatia, A., and Timmer, L. W. 2003. Evaluation of products for the control of Alternaria brown spot on Minneola tangelos, 2002. American Phytopathological Society, St. Paul, MN. Fungic. Nematicide Tests (online) Report 58:MO06.DOI.10.1094/FN58.

12. Bhatia, A., and Timmer, L. W. 2003. Evaluation of products for control of citrus greasy spot on grapefruit and oranges, 2001-02.
American Phytopathological Society, St. Paul, MN. Fungic. Nematicide Tests (online) Report 58:MO07.DOI.10.1094/FN58

13. Broadbent, P., Barchia, I., Hardy, S., and Timmer, L. W. 1996. Evaluation of fungicides for control of citrus scab and melanose on Eureka lemon. Fungic. Nematicide Tests 51:404

14. Bushong, P. M., and Timmer, L. W. 2000. Evaluation of postinfection control of citrus scab and melanose with benomyl, fenbuconazole, and azoxystrobin. Plant Dis. 84:12461249.

15. Canihos, Y., Peever, T. L., and Timmer, L. W. 1999. Temperature, leaf wetness, and isolate effects on infection of Minneola tangelo leaves by Alternaria sp. Plant Dis. 83:429-433.

16. Day, D. A., Whelan, J., Millar, A. H., Siedow, J. N., and Wiskich, J. T. 1995. Regulation of the alternative oxidase in plants and fungi. Aust. J. Plant Physiol. 22:497-509.

17. Forster, H., Kanetis, L., and Adaskaveg, J. E. 2004. Spiral gradient dilution, a rapid method for determining growth responses and 50\% effective concentration values in fungus-fungicide interactions. Phytopathology 94:163-170.

18. Ma, Z., Felts, D., and Michailides, T. 2003. Resistance to azoxystrobin in Alternaria isolates from pistachio in California. Pestic. Biochem. Physiol. 77:66-74.

19. McGrath, M. T., and Shishkoff, N. 2003. First report of the cucurbit powdery mildew fungus (Podosphaera xanthii) resistant to strobilurin fungicides in the United States. Plant Dis. 87:1007.

20. McGrath, M. T., Staniszewska, H., Shishkoff, N., and Casella, G. 1996. Fungicide sensitivity of Sphaerotheca fuliginea populations in the United States. Plant Dis. 80:697-703.

21. McManus, P. S., Best, V. M., Voland, R. P., and Leininger, B. L. 1999. Sensitivity of Monilinia oxycocci to fenbuconazole and propiconazole in vitro and control of cranberry cottonball in the field. Plant Dis. 83:445-450.

22. Mondal, S. N., Agostini, J. P., Zhang, L., and Timmer, L. W. 2004. Factors affecting pycnidium production of Diaporthe citri on detached citrus twigs. Plant Dis. 88:379-382.

23. Mondal, S. N., Gottwald, T. R., and Timmer, L. W. 2003. Environmental factors affecting the release and dispersal of ascospores of $M y$ cosphaerella citri. Phytopathology 93:10311036.

24. Mondal, S. N., and Timmer, L. W. 2003. Relationship of epiphytic growth of Mycosphaerella citri to greasy spot development on citrus and to disease control with fenbuconazole. Plant Dis. 87:186-192.

25. Olaya, G., and Koller, W. 1999. Baseline sensitivities of Venturia inaequalis populations to the strobilurin fungicide kresoxim-methyl. Plant Dis. 83:274-278.

26. Olaya, G., Zheng, D., and Koller, W. 1998. Differential responses of germinating conidia of Venturia inaequalis conidia to kresoximmethyl. Pestic. Sci. 54:230-236.

27. Pasche, J. S., Wharam, C. M., and Gudmestad, N. C. 2004. Shift in sensitivity of Alternaria solani in response to $\mathrm{Q}_{0} \mathrm{I}$ fungicides. Plant Dis. 88:181-187.

28. Peever, T. L., Canihos, Y., Olsen, L., Ibáñez, A., Liu, Y.-C., and Timmer, L. W. 1999. Population genetic structure and host specificity of Alternaria spp. causing brown spot of Minneola tangelo and rough lemon in Florida. Phytopathology 89:851-860.

29. Peever, T. L., Su, G., Carpenter-Boggs, L., and Timmer, L. W. 2004. Molecular systematics of citrus-associated Alternaria spp. Mycology 96:119-194.

30. Peres, N. A. R., Souza, N. L., Peever, T. L., and Timmer, L. W. 2004. Benomyl sensitivity of isolates of Colletotrichum acutatum and C. gloeosporioides from citrus. Plant Dis. 88:125-130.
31. Peres, N. A. R., Souza, N. L., and Timmer, L. W. 2000. Postbloom fruit drop in Brazil and Florida, occurrence and control by fungicides. Proc. IX Int. Soc. Citricult. Congr. 2000:10511052

32. Peres, N. A. R., and Timmer, L. W. 2003. Evaluation of products for the control of postbloom fruit drop (PFD) in screenhouse and field trials, 2001. American Phytopathological Society, St. Paul, MN. Fungic. Nematicide Tests (online) Report 58:MO05.DOI.10.1094/FN58

33. Reynolds, K. L., Brenneman, T. B., and Bertrand, P. F. 1997. Sensitivity of Cladosporium caryigenum to propiconazole and fenbuconazole. Plant Dis. 81:163-166.

34. Smith, F. D., Parker, D. M., and Koller, W. 1991. Sensitivity distribution of Venturia inaequalis to the sterol demethylation inhibitor flusilazole: Baseline sensitivity and implications for resistance monitoring. Phytopathology 81:392-396.

35. Timmer, L. W. 2002. Evaluation of fungicides for control of greasy spot on red grapefruit, 1999. American Phytopathological Society, St. Paul, MN. Fungic. Nematicide Tests (online) Report 57:M03.DOI.10.1094/FN57.

36. Timmer, L. W. 2002. Evaluation of fungicides for control of Alternaria brown spot on Murcotts. American Phytopathological Society, St. Paul, MN. Fungic. Nematicide Tests (online) Report 57:M08.DOI.10.1094/FN57.

37. Timmer, L. W. 2004. 2004 Florida Citrus Pest Management Guide. Univ. Florida Inst. Food \& Agric. Sci., Gainesville. Publ. No. SP-43.

38. Timmer, L. W., and Bushong, P. M. 2000. Evaluation of fungicides for control of citrus scab on Duncan grapefruit, 1999. Fungic. Nematicide Tests 55:567.

39. Timmer, L. W., Garnsey, S. M., and Graham, J. H., eds. 2000. Compendium of Citrus Diseases, 2nd ed. American Phytopathological Society, St. Paul, MN.

40. Timmer, L. W., Mondal, S. N., Peres, N. A. R., and Bhatia, A. 2003. Fungal diseases of fruit and foliage of citrus trees. Pages 191227 in: Disease Management of Fruits and Vegetables. K. G. Mujerki and S. A. M. H. Naqvi, eds. Kluwer Academic, Dordrecht, Netherlands.

41. Timmer, L. W., and Zitko, S. E. 2000. Evaluation of fungicides for control of postbloom fruit drop. 1998. Fungic. Nematicide Tests 55:571.

42. Vincelli, P., and Dixon, E. 2002. Resistance to $\mathrm{Q}_{0} \mathrm{I}$ (strobilurin-like) fungicides in isolates of Pyricularia grisea from perennial ryegrass. Plant Dis. 86:235-240.

43. Whiteside, J. O. 1980. Tolerance of Mycosphaerella citri to benomyl in Florida citrus groves. Plant Dis. 64:300-302.

44. Whiteside, J. O. 1980. Detection of benomyl tolerant strains of Elsinoe fawcettii in Florida citrus groves and nurseries. Plant Dis. 64:871872.

45. Whiteside, J. O. 1981. Diagnosis of citrus greasy spot based on experiences with this disease in Florida. Proc. V Int. Soc. Citricult. Congr. 1981:336-340.

46. Whiteside, J. O. 1986. Semiselective media for the isolation of Elsinoe fawcettii from citrus scab pustules. Plant Dis. 70:204-206.

47. Wong, F. P., and Wilcox, W. F. 2000. Distribution of baseline sensitivities to azoxystrobin among isolates of Plasmopara viticola. Plant Dis. 84:275-281.

48. Wong, F. P., and Wilcox, W. F. 2002. Sensitivity to azoxystrobin among isolates of Uncinula necator: Baseline distribution and relationship to myclobutanil sensitivity. Plant Dis. 86:394404.

49. Zitko, S. E., and Timmer, L. W. 1998. Evaluation of fungicides for control of citrus scab and melanose on grapefruit, 1996. Fungic. Nematicide Tests 53:490. 